\title{
FOOD EXPORTS COMPETITIVENESS IN E.U. BY COUNTRIES
}

\author{
José Ruiz Chico ${ }^{1, a, *}$, Antonio Rafael Peña Sánchez ${ }^{2, b}$ and Mercedes Jiménez \\ García $^{3, c}$
}

${ }^{1}$ Facultad de Ciencias Sociales y de la Comunicación. Avenida de la Universidad, s/n 11405 Jerez de la Frontera, Spain

${ }^{2}$ Facultad de Ciencias Sociales y de la Comunicación. Avenida de la Universidad, s/n 11405 Jerez de la Frontera, Spain

${ }^{3}$ Facultad de Ciencias Sociales y de la Comunicación. Avenida de la Universidad, s/n 11405 Jerez de la Frontera, Spain

ajose.ruizchico@uca.es*, brafael.pena@uca.es, ${ }^{c}$ mercedes.jimenezgarcia@uca.es

*Corresponding author

\begin{abstract}
The agri-food sector is characterized by being robust and strong, given its ability to resist economic crises in a better way. In the case of European Union, it is a leading sector in the world, for example, in terms of turnover. The main objective of this work is to analyse the competitiveness of the European Union agri-food exports by countries in 2004-2013, in the context of their total exports, by determining their different elasticities. This is an original approach in economic literature as it is not based on the traditional Shift-Share analysis. In this context, indicators such as the elasticities of regional and sectoral development has been estimated in order to indentify the strongest and the weakest countries about this question. The results of the research lead to the conclusion that European agri-food sector is a highly competitive activity in international trade. At a country level, important differences between Eastern and Western countries can be highlighted. Eastern countries would be more competitive in agri-food exports, mainly Bulgaria, Latvia, Lithuania and Poland. Western countries offer a quite different profile, as their agrifood indicators are acceptable but not as positive as theirs. This may be because they can have their competitive strengths in other more capital intensive sectors, located within the secondary and tertiary sectors. Spain, Portugal, France and Germany stand out but not with so strong indicators as Eastern countries. The most critical countries in these variables would be United Kingdom, Finland, Luxembourg and Denmark, whose indicators would be below average.
\end{abstract}

Keywords: Agriculture, development, elasticities, international trade.

JEL Classification: F43. L66. O13.

\section{Introduction}

This work has as main objective the analysis of the competitiveness of the agri-food exports of the European Union at the level of its Member States. With this general intention, their elasticities will be studied between 2004 and 2013, by means of an original approach in Economics beyond the traditional Shift-Share analysis.

The agri-food sector consists of the primary sector, which is composed by agriculture, livestock, forestry and fisheries; and also of the agri-food industry, which would include the transformative activities (Caldentey, 1985). FoodDrinkEurope (2015) describes the European food industry as a robust sector, which is set as a core one, because it has a significant weight 
in all countries. Besides that, it could be a major strength in Europe, especially for developing countries, as the demand is more stable facing economic fluctuations. Authors such as Cadenas and Cantero (1997), Park (2009), Csáki and Buchenrieder (2013), MERCASA (2012), Fedoseeva (2014), Cheptea et al (2014) and Bojnec and Fertö (2015) support these ideas.

In order to define a framework about its importance, Tab. 1 shows the global data by countries in the world. Compared to other main producers, the European agri-food sector would be a leader in terms of turnover, although its contribution to the industrial sector is lower than in other countries such as Brazil (22\%), Australia (23\%), Canada (16\%) and New Zealand $(47 \%)$. In terms of number of enterprises and workers, it is only surpassed by China, which has 400.000 companies and 6.7 million workers in this sector.

Table 1: Main macroeconomic variables of the agri-food sector by countries (2012/2013).

\begin{tabular}{lllll}
\hline & $\begin{array}{l}\text { Number of employees } \\
\text { (Thousands) }\end{array}$ & Number of companies & $\begin{array}{l}\text { Turnover } \\
\text { (Billions } € \text { ) }\end{array}$ & $\begin{array}{l}\text { Turnover over } \\
\text { industrial sector (\%) }\end{array}$ \\
\hline European Union & 4.220 & 289.000 & 1.244 & 15 \\
China & 6.740 & 400.000 & 767 & 11 \\
U.S.A. & 1.414 & 25.789 & 578 & 13 \\
Japan & 1.427 & 59.458 & 466 & 12 \\
Brazil & 1.626 & 32.000 & 169 & 22 \\
Mexico & 793 & 170.000 & 102 & 12 \\
Russia & $1300(2009)$ & 43.016 & 99 & 15 \\
India & 1700 & 36.881 & 95 & 9 \\
Canada & 288 & 6.526 & 72 & 16 \\
Australia & 220 & 2.507 & 62 & 23 \\
South Korea & 179 & 23.929 & 32 & 6 \\
New Zealand & 81 & 3.302 & 27 & 47 \\
\hline
\end{tabular}

Source: Eurostat and FoodDrinkEurope (2015).

FoodDrinkEurope (2015) explains that this is the largest manufacturing sector in E.U. in terms of turnover (1.244 billion $€$ in 2013) and added value (206 billion $€$ in 2012). In fact, this is a more important contributor to the European economy than other sectors such as machinery, automotive or metal. It is also the leading sector in employment in Europe, with 4.2 million workers, which would suppose $15 \%$ of the total manufacturing sector, more than, for example, in the case of the sectors of metallic products $(11.6 \%)$ or machinery and equipment $(10.1 \%)$. This organization considers that it creates a relatively stable employment, although with a lower productivity than most manufacturing subsectors ( $€ 46.000$ / worker, below $€ 92.000$ / worker in chemical sector, $€ 66.000$ / worker in automotive sector, $€ 65.000$ / worker of machinery and equipment or $€ 54.000$ / worker of the manufacturing sector). By countries, it is shown in Tab. 2 that $66 \%$ of turnover is controlled by the five major E.U. members (Germany, France, Italy, United Kingdom and Spain).

FoodDrinkEurope (2015) also explains that this industry in E.U. is a highly diversified sector according to the number of companies, as more than $50 \%$ of turnover is generated by small and medium companies. As it can be seen in the Tab. 3. it includes a wide variety of sectors ranging from fruits and vegetables to processing for the production of dairy products and beverages. The most important food subsectors (meat products, others, beverages, dairy products and bakery and farinaceous products) represent $75 \%$ in the European agri-food sector. 
Table 2: Main macroeconomic variables of the agri-food sector per E.U. countries (2013).

\begin{tabular}{|c|c|c|c|c|}
\hline Example & $\begin{array}{l}\text { Number of } \\
\text { employees } \\
\text { (Thousands) }\end{array}$ & $\begin{array}{l}\text { Number of } \\
\text { companies }\end{array}$ & $\begin{array}{l}\text { Turnover } \\
\text { (Billions } € \text { ) }\end{array}$ & $\begin{array}{l}\text { Added value } \\
\text { (Billions } € \text { ) }\end{array}$ \\
\hline Austria $^{(1)}$ & 64 & 3.818 & 20.3 & 5.1 \\
\hline Belgium & 88.8 & 4.638 & 48.2 & 7.4 \\
\hline Bulgaria & 94.3 & 5.833 & 4.9 & $0.8^{(4)}$ \\
\hline Croatia & 62.9 & 3.240 & 5.2 & $1.2^{(4)}$ \\
\hline Denmark & 53 & 630 & 24.6 & 3 \\
\hline Estonia & 14.3 & 490 & 1.8 & 2.5 \\
\hline Finland & 33.5 & 1769 & 11.3 & 2.5 \\
\hline France & 492.2 & $15.788(4)$ & 158.9 & 10.8 \\
\hline Germany (2) & 555.3 & 5.920 & 175.2 & 34.2 \\
\hline Greece $(3)$ & 78 & 1.320 & 14.5 & 1.5 \\
\hline Hungary & 94 & 6.574 & 11.4 & 2.4 \\
\hline Ireland & 39.2 & 607 & 26.4 & 7.6 \\
\hline Italy & 385 & $6.850(4)$ & 132 & $22.1^{(4)}$ \\
\hline Latvia & 26.2 & 959 & 1.3 & $0.3^{(4)}$ \\
\hline Lithuania & 42.8 & 1.468 & 4 & $0.6^{(4)}$ \\
\hline Netherlands & 133 & 5.035 & 62.4 & 13.3 \\
\hline Poland & 419.8 & 14.218 & 55.2 & 10 \\
\hline Portugal & 107 & 10.421 & 14.9 & 2.6 \\
\hline Reino Unido & 402 & 6.020 & 113.6 & 31 \\
\hline Romania & 183.1 & 8.566 & 11.2 & $1.9^{(4)}$ \\
\hline Slovakia ${ }^{(3)}$ & 28 & 2.766 & 4.5 & 0.7 \\
\hline Slovenia & 15.9 & 1.938 & 2.1 & $0.4^{(4)}$ \\
\hline Spain & 447.8 & 27.199 & 91.5 & 28.4 \\
\hline Sweden & 50.5 & 3.784 & 19.5 & $\begin{array}{l}20.7 \\
4.6\end{array}$ \\
\hline United Kingdom & 100.4 & 8.415 & 13.8 & 2.3 \\
\hline
\end{tabular}

* Cyprus, Luxembourg and Malta do not appear due to non-relevant values.

(1) Just companies with more than 10 employees.

(2) Just companies with more than 20 employees.

(3) Small companies not included.

(4) Date for 2012.

Source: Eurostat and FoodDrinkEurope (2015).

Table 3: Weight of each agri-food subsector within the European Union (\%) (2012).

\begin{tabular}{|c|c|c|c|c|}
\hline & Employees & Companies & Turnover & Added value \\
\hline Meat products. & 32 & 54 & 20 & 21 \\
\hline Drinks. & 14 & 9 & 14 & 18 \\
\hline Dairy products. & 9 & 8 & 13 & 15 \\
\hline $\begin{array}{l}\text { Bakery and farinaceous } \\
\text { products. }\end{array}$ & 8 & 4 & 11 & 10 \\
\hline Animal feeding. & 6 & 4 & 7 & 6 \\
\hline $\begin{array}{l}\text { Processed fruits and } \\
\text { vegetables. }\end{array}$ & 3 & 3 & 6 & 5 \\
\hline Oils and fats. & 3 & 2 & 5 & 3 \\
\hline $\begin{array}{l}\text { Products of milling and } \\
\text { starches. }\end{array}$ & 2 & 2 & 4 & 2 \\
\hline Fish and seafood. & 1 & 1 & 2 & 1 \\
\hline
\end{tabular}

Source: Eurostat and FoodDrinkEurope (2015).

This work is composed by the following sections. After introducing agri-food sector in Europe in this point, the methodology is explained in the next section. In the third one, European agri-food exports are studied in the context of the total ones. Elasticities of regional and sectoral development are also presented. The fourth section analyses the sectoral elasticities of attraction and location and also Share and Shift elasticities. Finally, this work ends with the main conclusions and bibliography. 


\section{Methodology}

The main objective of this work is to analyse the competitiveness of European Union agrifood exports by countries, in the context of their total exports, by determining their different elasticities. The aim is to identify the comparatively stronger and weaker countries which could find a possible competitive advantage in the agri-food sector from a foreign trade perspective.

According to authors such as Kitson et al (2004), Morley \& Morgan (2008), Kandilov \& Zheng (2011), Maertens (2011), Ucak et al. (2012), Baiardi et al. (2015) exports would be an appropriate variable to measure the competitiveness of a certain sector. This work has a relatively innovative approach because although there are several works about this topic, there are not many studies based on elasticities. The Shift-Share analysis, proposed by Dunn (1960) and later revised by authors such as Esteban - Marquillas (1972), is very useful explaining the causes the growth of a certain variable, separating it to explain regional differences. The ShiftShare components can be expressed as elasticities, to describe regional dynamics (Esteban Marquillas, 1986; Girardi, 1993). This analysis improves the traditional approach because the results supports an explanatory treatment, relating the growth mechanisms to space more directly.

These methodologies have been widely used in studies of regional economics (Ezcurra \& Rapún, 2006. Reig, 2007. Mayor et al, 2005 and 2008. Maudos et al, 2008). It has also been studied in studies about the growth of employment (Ezcurra et al, 2005. Suedekum et al., 2006. Mayor \& López, 2008. Cörvers \& Meriküll, 2007), as well as in the analysis of sectors as varied as tourism (Sirakaya et al., 2002) or the manufacturing industry (Dinc \& Haynes, 1999; Zhao et al., 2006; Castaldi, 2009). In the field of foreign trade, it has been applied by Hellman (1974), Markusen et al (1991), Gazel \& Schwer (1998), Williamson (2006) and Minondo and Requena (2012). At the agri-food level, the works of Serrano and Pinilla Navarro $(2010,2011)$ can be highlighted as well.

The main indicators are presented below, showing their results later in Tab. 5. The first indicator is the elasticity of regional development. This variable estimates the reaction of total exports of a country $\left(y_{\bullet}^{r}\right)$ compared to the growth of global exports of E.U. $\left(y_{\bullet}^{\bullet}\right)$. It is calculated as follows:

$$
E_{\text {r... }}=\left[\begin{array}{c}
\frac{\Delta y_{*}^{r}}{y_{*}^{r}} \\
\frac{\Delta \dot{y}_{*}^{*}}{y_{*}^{*}}
\end{array}\right]=\left[\frac{\Delta y_{*}^{r}}{\Delta y_{*}^{*}}\right]\left[\frac{y_{*}^{*}}{y_{*}^{*}}\right]
$$

The elasticity of sectoral development will be calculated by means of the formula number (2). It measures how agri-food exports $\left(y_{i}^{\bullet}\right)$ react for increases in total exports in the E.U. $\left(y_{\bullet}^{\bullet}\right)$.

$$
\left.E_{\text {oi. }}=\left[\frac{\frac{\Delta y_{i}^{*}}{y_{i}^{*}}}{\frac{\Delta y_{i}^{*}}{y_{*}^{*}}}\right]=\left[\frac{\Delta y_{i}^{*}}{\Delta y_{*}^{*}}\right] \frac{y_{i}^{*}}{y_{i}^{*}}\right]
$$

The elasticity of sectoral location is also analysed, reflecting how agri-food exports react $\left(y_{i}^{\prime}\right)$ in comparison with the growth of agri-food exports in E.U. $\left(y_{i}^{*}\right)$. This index is very important to measure the potential qualities of location. In this way, the variable object of study 
has been benefited from the conditions offered by the country, so if it presents values above the unit in this elasticity, it means that it has grown above the total aggregate. It is calculated as:

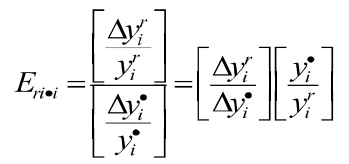

The elasticity of sectoral attraction measures the reaction of the sector's exports in a country $\left(y_{i}^{r}\right)$ related to the growth of total exports in it $\left(y_{\bullet}^{r}\right)$. Its expression would be:

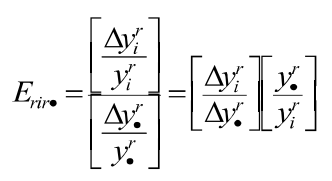

Girardi (1993) offers an interesting proposal for the growth of exports of a sector in a certain country $\left(\Delta y_{i}^{r}=E_{r i v i}\left(C E_{i}^{r} a_{0}^{r}\right) \Delta y_{i}^{*}\right)$ based in the expression of the elasticity of sectoral location. This expression is placed in the elasticity of regional development, obtaining:

$$
\left.\left.E_{r \ldots .}=\left[\frac{\Delta y_{\bullet}^{r}}{\Delta y_{\bullet}^{\bullet}}\right] \frac{y_{\bullet}^{\bullet}}{y_{\bullet}^{r}}\right]=\left[\frac{\sum_{i=1}^{I} E_{r i \bullet i}\left(C E_{i}^{r} a_{\bullet}^{r}\right) \Delta y_{i}^{\bullet}}{\Delta y_{\bullet}^{*}}\right] \frac{1}{a_{\bullet}^{r}}\right]=\sum_{s=1}^{I} E_{\text {oi } \bullet \bullet} E_{r i \bullet i} a_{i}^{\bullet} C E_{i}^{r}
$$

The following formula is reached adding and subtracting 1:

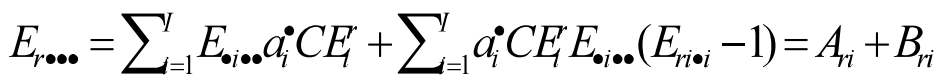

Abbreviated as $\mathrm{A}_{\mathrm{ri}}$ and $\mathrm{B}_{\mathrm{ri}}$, these terms are also known as Share elasticity, which shows what would have happened in a country if its sectors had grown at the same rate as E.U., and Shift elasticity, which reflects the real growth of each country. Share elasticity presents a value greater than unity when its sectoral structure is well designed. Shift elasticity will be favourable if the characteristics of the country are well adapted to their needs, presenting positive values in this case. Girardi (1993) simplifies these expressions as:

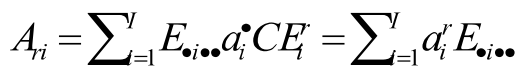

$$
\begin{aligned}
& B_{r i}=\sum_{i=1}^{I} a_{i}^{*} C E_{1}^{r} E_{\text {oi } . .0}\left(E_{r i \bullet i}-1\right)=\sum_{=1}^{I} a_{i}^{r} E_{r i \bullet}^{*}
\end{aligned}
$$

being $E_{r i \dot{ }}^{*}=E_{\text {oi } \bullet \bullet}\left(E_{r i \bullet i}-1\right)$ and $a_{i}^{r}=\left(\frac{y_{i}^{r}}{y_{\bullet}^{r}}\right)$.

The variables used in this work are total and food exports of the Member States of E.U. for 2004-2013. These data, provided by EUROSTAT, have been deflated to 2004 prices by the Harmonised Indices of Consumer Prices (HICP). The development is carried out below.

\section{Analysis of agri-food exports in the E.U. (2004-2013), in the context of total exports}

This section studies the evolution of agri-food exports in 2004-2013 for the Member States of the E.U. To analyse its relevance, these variables should be focused on the context of total exports by countries. They are shown in Tab. 4. where it can be seen that they have increased by $24.12 \%$ in constant terms in 2004-2013. 
Table 4: Total and agri-food exports of E.U. (2004-2013) (Billion $€$ ).

\begin{tabular}{|c|c|c|c|c|c|c|}
\hline & \multicolumn{3}{|c|}{ Total Exports } & \multicolumn{3}{|c|}{ Agri-food Exports } \\
\hline & $2004 *$ & $2013^{*}$ & $\%$ Growth ** & $2004 *$ & $2013^{*}$ & $\%$ Growth** \\
\hline Austria & 95.2 & 131.9 & 14.2 & 5.4 & 9.5 & 43.9 \\
\hline Belgium & 246.7 & 352.9 & 16.6 & 20.1 & 31.0 & 25.4 \\
\hline Bulgaria & 8.0 & 22.3 & 81.2 & 0.7 & 3.1 & 172.8 \\
\hline Croatia & 6.4 & 9.5 & 14.4 & 0.6 & 1.1 & 49.0 \\
\hline Cyprus & 0.8 & 1.5 & 62.9 & 0.2 & 0.3 & 24.8 \\
\hline Czech Rep. & 55.5 & 122.2 & 77.9 & 1.8 & 5.3 & 141.7 \\
\hline Denmark & 62.0 & 82.9 & 12.4 & 11.5 & 15.4 & 12.3 \\
\hline Estonia & 4.8 & 12.3 & 72.5 & 0.3 & 1.2 & 130.4 \\
\hline Finland & 49.5 & 56.0 & -6.6 & 0.9 & 1.5 & 37.3 \\
\hline France & 363.5 & 437.4 & 2.8 & 36.3 & 55.3 & 30.3 \\
\hline Germany & 731.5 & 1093.1 & 27.1 & 30.8 & 61.2 & 69.2 \\
\hline Greece & 13.2 & 27.6 & 66.1 & 2.5 & 4.2 & 33.0 \\
\hline Hungary & 44.7 & 80.9 & 20.9 & 2.7 & 6.6 & 63.7 \\
\hline Ireland & 84.2 & 86.1 & -8.5 & 7.1 & 9.9 & 24.9 \\
\hline Italy & 284.4 & 390.2 & 12.7 & 17.6 & 29.9 & 39.9 \\
\hline Latvia & 3.2 & 10.9 & 115.0 & 0.3 & 2.1 & 380.4 \\
\hline Lithuania & 7.5 & 24.5 & 128.7 & 0.8 & 4.3 & 271.5 \\
\hline Luxembourg & 13.0 & 13.9 & -16.5 & 0.6 & 1.0 & 21.1 \\
\hline Malta & 2.0 & 2.7 & 9.9 & 0.1 & 0.2 & 57.9 \\
\hline Netherlands & 287.3 & 505.6 & 49.2 & 38.5 & 63.7 & 40.1 \\
\hline Poland & 60.3 & 154.3 & 99.6 & 5.0 & 19.0 & 198.6 \\
\hline Portugal & 28.8 & 47.3 & 38.3 & 2.1 & 4.9 & 100.3 \\
\hline Romania & 18.9 & 49.6 & 57.3 & 0.4 & 4.2 & 481.2 \\
\hline Slovakia & 22.3 & 64.6 & 129.1 & 0.7 & 2.5 & 175.4 \\
\hline Slovenia & 13.2 & 25.6 & 53.6 & 0.4 & 1.4 & 205.6 \\
\hline Spain & 146.8 & 238.4 & 29.8 & 19.4 & 33.5 & 38.3 \\
\hline Sweden & 99.1 & 126.1 & 10.9 & 3.1 & 7.1 & 97.6 \\
\hline UK. & 279.4 & 407.3 & 13.2 & 15.4 & 22.2 & 11.6 \\
\hline
\end{tabular}

Note: *Current values $\quad * *$ Constant Values (Base 2004).

Source: Prepared by author based on Eurostat

In this case, Eastern countries have a more relevant growth in total exports, especially the cases of Slovakia (129.1\%), Lithuania (128.7\%) and Latvia (115.0\%). Western countries have a lower growth, mainly Finland (-6.6 \%), Ireland (-8.5\%) and Luxembourg (-16.5\%), the only three countries with decreases in their exports. In the group of veteran countries, Greece stands out for its high growth $(66.13 \%)$, while Hungary is the country with the lowest increase (20.9 $\%)$.

Agri-food exports must be analysed specifically. According to FoodDrinkEurope (2015) the European Union is the world's largest exporter of food, controlling $18 \%$ of them, over the United States (12\%). This share fallen 2 points in the last decade because of the boom of China and Brazil. However, European agri-food exports doubled in the last decade, thus showing the relevance of the sector. This percentage is higher than the increase in imports, which only grew by $50 \%$ in this period. More than a quarter of these exports are sold outside Europe, with a positive evolution, excepting Russia.

Agri-food foreign trade has a positive balance with all regions of the world, except for ASEAN in Asia, and Mercosur and Andean Countries in America. Going into detail, NAFTA would be the main external market for the European Union, where the United States specifically accounts for 14.5 billion euros in agri-food exports and 4.9 billion in imports. China would also have a very remarkable weight, raising these variables to 5.6 and 3.7 respectively. Within the group of EFTA countries, Switzerland is a very relevant market with 5.3 and 4.1 in these variables. Finally, it is worth noting the importance of Russia ( $€ 6.3$ billion in agri-food exports), as well as Brazil and Argentina as the origin of these imports ( $€ 6.7$ and 4.341 billion $€)$. 
By products, the trade balance would be positive in all cases except processed fruits and vegetables as well as oils and fats. The beverages sector can be especially highlighted, with an export market share of $28 \%$, which together with dairy and meat products would reach a total share of $52 \%$, dominating the agri-food sector.

The values of these exports are also listed in Tab. 4. This sector has increased its weight in total exports of E.U. from being $7.43 \%$ of the total in 2004. to $8.76 \%$ in 2013. On average, agricultural exports grew by $46.4 \%$ in this decade, a rate which almost doubles global ones (24.12\%). Their evolution can be highlighted in the case of Eastern European countries, especially Romania (481.2 \%), Latvia (380.4\%) and Lithuania (271.5\%), where these exports appear as real strengths. On the contrary, the Western countries show a more moderate growth, mainly in Luxembourg (21.1\%), Denmark (12.3\%), United Kingdom (11.6\%), with the lowest values throughout the European Union. It can be seen also, that in most countries the growth of agri-food exports is always higher than total exports, with the exception of Cyprus, Denmark, Greece, Netherlands and United Kingdom. This difference is especially interesting in the cases of Romania, Latvia, Slovenia, Lithuania and Poland.

With these data, the elasticity of regional development, presented as expression number 1. has be calculated. The results are showed in Tab. 5. where can be seen that most of the countries of Eastern Europe have increased their exports. Particularly noteworthy are Slovakia (5.3510), Lithuania (5.3381) and Latvia (4.7696). Western countries have worse indicators showing further weakness, being even negative such in the cases of Finland (-0.2729), Ireland (-0.3506) and Luxembourg (-0.6851).

Finally, the elasticity of sectoral development has been studied. This expression was introduced in the methodology as expression number 2. According to this variable, the food industry (1.9236) would be shown stronger than the non agri-food one (0.9259), which offers a lower value facing the growth of total exports.

This section can be concluded by stating that, from the point of view of exports, the European food industry is quite strong, being above the average of the European external sector. Eastern European countries stand out showing positive values in all the indicators, especially Bulgaria, Croatia, Latvia, Lithuania and Poland. In fact, Western countries have lower values, especially United Kingdom. France would be the country with a more positive profile.

\section{Other elasticities applied to European food exports}

In this section other regional dynamics will be described through other elasticities such as the elasticities of sectoral attraction and location. As these elasticities relate regional growth to the conditions in which it has occurred, a characteristic profile can be established for each country.

Firstly, the elasticity of agri-food location has been calculated through the expression number 3. The results are shown in Tab. 5. This elasticity is always positive, unlike what happens in non-agri-food sectors, where four countries have negative values. Eastern countries stand out, especially Romania (10.3714) and Latvia (8.1982). Among Western countries, only Portugal (2.1621), Sweden (2.1046) and Germany (1.4906) have higher values than unity. Luxembourg (0.4549), Denmark (0.2657) and United Kingdom (0.2501) offer the most critical values. Ten countries of E.U. have a non agri-food elasticity higher than the agri-food one, where the cases of the Netherlands, Slovakia, Greece and Cyprus can be emphasized. 
Table 5: Several Elasticities.

\begin{tabular}{|c|c|c|c|c|c|c|c|}
\hline & $\begin{array}{l}\text { Regional } \\
\text { development }\end{array}$ & $\begin{array}{l}\text { Agr. sectoral } \\
\text { location }\end{array}$ & $\begin{array}{l}\text { Non Agr. } \\
\text { sectoral } \\
\text { location }\end{array}$ & $\begin{array}{l}\text { Agr. sectoral } \\
\text { attraction }\end{array}$ & $\begin{array}{l}\text { Non Agr. } \\
\text { sectoral } \\
\text { attraction }\end{array}$ & $\begin{array}{l}\text { Share } \\
\text { elasticity }\end{array}$ & $\begin{array}{l}\text { Shift } \\
\text { elasticity }\end{array}$ \\
\hline Austria & 0.5906 & 0.9453 & 0.5578 & 3.0790 & 0.8744 & 0.9827 & -0.3921 \\
\hline Belgium & 0.6898 & 0.5485 & 0.7100 & 1.5294 & 0.9530 & 1.0073 & -0.3175 \\
\hline Bulgaria & 3.3672 & 3.7254 & 3.2257 & 2.1283 & 0.8870 & 1.0167 & 2.3505 \\
\hline Croatia & 0.5978 & 1.0558 & 0.4991 & 3.3977 & 0.7731 & 1.0121 & -0.4144 \\
\hline Cyprus & 2.6105 & 0.5338 & 3.3640 & 0.3933 & 1.1931 & 1.1668 & 1.4437 \\
\hline Czech Rep. & 3.2311 & 3.0551 & 3.3949 & 1.8189 & 0.9728 & 0.9579 & 2.2732 \\
\hline Denmark & 0.5135 & 0.2657 & 0.5551 & 0.9954 & 1.0011 & 1.1108 & -0.5974 \\
\hline Estonia & 3.0054 & 2.8106 & 3.0495 & 1.7989 & 0.9394 & 0.9962 & 2.0093 \\
\hline Finland & -0.2729 & 0.8033 & -0.3301 & -5.6627 & 1.1200 & 0.9435 & -1.2164 \\
\hline France & 0.1173 & 0.6525 & -0.0096 & 10.7001 & -0.0759 & 1.0255 & -0.9082 \\
\hline Germany & 1.1245 & 1.4906 & 1.1318 & 2.5500 & 0.9319 & 0.9679 & 0.1566 \\
\hline Greece & 2.7415 & 0.7116 & 3.3143 & 0.4993 & 1.1193 & 1.1179 & 1.6236 \\
\hline Hungary & 0.8657 & 1.3730 & 0.8129 & 3.0509 & 0.8694 & 0.9856 & -0.1199 \\
\hline Ireland & -0.3506 & 0.5373 & -0.5158 & -2.9483 & 1.3621 & 1.0097 & -1.3603 \\
\hline Italy & 0.5267 & 0.8602 & 0.4887 & 3.1413 & 0.8591 & 0.9875 & -0.4607 \\
\hline Latvia & 4.7696 & 8.1982 & 4.0210 & 3.3064 & 0.7806 & 1.0126 & 3.7571 \\
\hline Lithuania & 5.3381 & 5.8515 & 4.9912 & 2.1086 & 0.8657 & 1.0337 & 4.3044 \\
\hline Luxembourg & -0.6851 & 0.4549 & -0.8272 & -1.2771 & 1.1179 & 0.9750 & -1.6601 \\
\hline Malta & 0.4126 & 1.2484 & 0.3257 & 5.8199 & 0.7308 & 0.9786 & -0.5660 \\
\hline Netherlands & 2.0383 & 0.8635 & 2.2646 & 0.8149 & 1.0287 & 1.0597 & 0.9786 \\
\hline Poland & 4.1303 & 4.2793 & 4.0641 & 1.9930 & 0.9110 & 1.0079 & 3.1224 \\
\hline Portugal & 1.5891 & 2.1621 & 1.5031 & 2.6173 & 0.8758 & 0.9970 & 0.5920 \\
\hline Romania & 2.3757 & 10.3714 & 2.1206 & 8.3978 & 0.8265 & 0.9487 & 1.4270 \\
\hline Slovakia & 5.3510 & 3.7796 & 5.7107 & 1.3587 & 0.9881 & 0.9579 & 4.3931 \\
\hline Slovenia & 2.2245 & 4.4314 & 2.2138 & 3.8321 & 0.9214 & 0.9528 & 1.2716 \\
\hline Spain & 1.2356 & 0.8250 & 1.2768 & 1.2845 & 0.9567 & 1.0576 & 0.1780 \\
\hline Sweden & 0.4511 & 2.1046 & 0.3605 & 8.9747 & 0.7400 & 0.9574 & -0.5063 \\
\hline UK. & 0.5490 & 0.2501 & 0.5972 & 0.8762 & 1.0072 & 0.9810 & -0.4320 \\
\hline
\end{tabular}

Source: Prepared by author based on Eurostat

The following indicator would be the elasticity of sectoral attraction has been studied, according to the expression number 4 and whose results appear in Tab. 5. Luxembourg (1.2771), Ireland (-2.9483) and Finland (-5.6627) would be the countries with the most negative agri-food conditions, being stronger in non agri-food exports. Denmark (0.9954), United Kingdom (0.8762), the Netherlands (0.8149), Greece (0.4993) and Cyprus (0.393) would join this list of weaker countries because of their elasticities lower than unit. It should be also noted that 20 countries would have favourable conditions to attract foreign activity in this sector, due to their elasticities above unity, implying that they receive important positive impulses to grow. France (10.7001), Sweden (8.9747) and Romania (8.3978) stand out in this regard.

Tab. 5 also shows that the elasticity of agri-food attraction is higher than the non agri-food ones in the most of the E.U. countries. In cases such as France, Sweden, Romania and Malta, the difference is very remarkable, especially for the excellent value presented by the agri-food sector.

Share and Shift elasticities, presented in expressions number 7 and 8. are listed in Tab. 5. Share elasticity presents positive values, because their are higher than unity, mainly in Denmark (1.1108), Greece (1.1179) and Cyprus (1.1668), showing that the regional structure is well designed. Instead, Finland (0.9435), Romania (0.9487), Slovenia (0.9528), Sweden (0.9574), Slovakia (0.9579) and Czech Rep. (0.9579) have some deficiencies.

Shift elasticity will be favourable, having positive values, in the cases countries such as Slovakia (4.3931), Lithuania (4.3044), Latvia (3.7571), Poland (3.1224) and Bulgaria (2.3505), which stand out in this situation. The opposite situation happens in Denmark (-0.5974), France 
(-0.9082), Finland (-1.2164), Ireland (-1.3603) and Luxembourg (-1.6601). Finally, based on these elasticities, this typology of countries can be built:

I. Countries Type I (Shift elasticity $>0$ and Share elasticity $>1$ ): Lithuania, Latvia, Poland, Bulgaria, Greece, Cyprus, Netherlands and Spain. The sectoral structure of these countries affects their growth positively, with a suitable allocation of factors for it.

II. Countries Type II (Shift elasticity $<0$ and Share elasticity $>1$ ): Belgium, Croatia, Denmark, France and Ireland. They present a model of development based on very dynamic sectors, but there are some negative conditions which can limit it according to their sectoral structure.

III. Countries Type III (Shift elasticity $>0$ and Share elasticity $<1$ ): Slovakia, Czech Rep., Estonia, Romania, Slovenia, Portugal and Germany. The sectoral structure operates well, although it is not optimal, being based on mature sectors.

IV. Countries Type IV (Shift elasticity $<0$ and Share elasticity $<1$ ): Hungary, Austria, United Kingdom, Italy, Sweden, Malta, Finland and Luxembourg. There are problems of growth, because they have a not well designed sectoral structure, having some sectors in crisis.

To sum it up, the Eastern European countries stand out one more time, mainly Bulgaria, Latvia, Lithuania and Poland, which present positive indicators. In general, Western countries have more critical values, especially United Kingdom, Finland and Luxembourg, which do not stand out in any particular indicator. Only Germany, Portugal and Spain offer a more positive profile, although with some weakness in Share elasticity in the first two cases, and in the location elasticity in Spain.

\section{Discussion and conclusion}

The European agri-food industry can be configured as a stable and solid sector from an export perspective, following the results obtained for the period 2004-2013. It can be said then that this is a highly competitive sector in the field of foreign trade due to the following reasons:

- The first evidence confirming this approach is the fact that agri-food exports increased by $46.4 \%$ in $2004-2013$, practically twice as much as total exports $(24.12 \%)$.

- The elasticity of agri-food development (1.9236) also doubles that of non agri-food sectors (0.9259), offering very positive values.

At the country level, important differences between Eastern and Western countries can be highlighted, following the view of Cadenas \& Cantero (1997) and Csáki \& Buchenrieder (2013). Firstly, Eastern countries would be more competitive in agri-food exports but much weaker economically, with a large primary sector weight in their economies, having more weaknesses in industry and services. These are countries which, in general, have been benefited from joining the European Union because of the great possibilities it offers, having also received European funds for its development.

Among these countries, Bulgaria, Latvia, Lithuania and Poland are the most important ones. Estonia and Croatia would also present an interesting profile although the first country has deficiencies with its Share elasticity. Croatia, on the other hand, would have a low regional 
development in exports and a negative Shift elasticity. Hungary and Malta would be the weakest countries in this group, although they would be above average.

Western countries are the most veteran in the European Union and those who also have a more mature structure, offering a quite different profile from those of Eastern Europe. Their agrifood indicators are quite acceptable but not as resounding or positive as theirs. This may be produced, because they can have their competitive strengths in other more capital intensive sectors, located within the secondary and tertiary sectors.

Particularly noteworthy are Spain and Portugal, countries with a great agro-food tradition but with some shadows. For example, Spain has a location elasticity of less than unity. Portugal, on the other hand, would have an improved Share elasticity. Germany and France would also stand out with not so strong data. Obviously they have other sources of specialization in the context of foreign trade. At the other extreme, the most critical countries in these variables would be United Kingdom, Finland, Luxembourg and Denmark. United Kingdom and Denmark only have the strong growth of both their agri-food exports and the global ones, but below the average. Agri-food exports from Finland and Luxembourg rise while total exports decrease.

Finally, this work should be concluded considering future revisions of the same, as well as extensions as new data become available. These conclusions may be useful in formulating more specific development policies for those countries which can find an ally in agri-food sector, given their strength in the foreign market.

\section{References}

[1] Baiardi, D., Bianchi, C., \& Lorenzini, E. (2015). Food competition in world markets: Some evidence from a panel data analysis of top exporting countries. Journal of agricultural economics, vol. 66, no. 2, pp. 358-391.

[2] Bojnec, Š., \& Fertő, I. (2015). Agri-Food Export Competitiveness in European Union Countries. Journal of Common Market Studies, vol. 53, no. 3, pp. 476-492.

[3] Cadenas, A., \& Cantero, C. (1997). Implicaciones agroalimentarias de la adhesión de los países de Europa Central y Oriental a la Unión Europea. Madrid, Spain: Ministerio de Agricultura, Alimentación y Medio Ambiente.

[4] Caldentey, P. (1985). El sistema agroalimentario en los países occidentales. Revista de Estudios Agrosociales, vol. 131, pp. 167-186.

[5] Castaldi, C. (2009). The relative weight of manufacturing and services in Europe: An innovation perspective. Technological Forecasting \& Social Change, vol. 76, pp. 709722 .

[6] Cheptea, A., Emlinger, C.H., \& Latouche, K. (2014). Multinational Retailers and Home Country Food Exports. American journal of agricultural economics, vol. 97, no. 1, pp. 159-179. doi: 10.1093/ajae/aau017

[7] Cörvers, F., \& Meriküll, J. (2007). Occupational structures across 25 EU countries: the importance of industry structure and technology in old and new EU countries. Economic Change, vol. 40, pp. 327-359. doi: 10.1007/s10644-008-9035-7 
[8] Csáki, C., \& Buchenrieder, G. (2013). Effects of the financial and economic crisis on the rural landscape as well as the agri-food sector in Europe and central Asia. Society and Economy, vol. 33, no. 2, pp. 249-270. doi: 10.1556/SocEc.33.2011.2.2

[9] Dinc, M., \& Haynes K.E. (1999). Regional Efficiency in the Manufacturing Sector: Integrated Shift-Share and Data Envelopment Analysis. Economic Development Quarterly, vol. 13, pp. 183-211. doi: 10.1177/089124249901300207

[10] Dunn, E.S. (1960). A statistical and analytical technique for regional analysis. Papers of the Regional Science Association, vol. 6, pp. 97-112. doi: 10.1111/j.14355597.1960.tb01705.x

[11] Esteban-Marquillas, J.M. (1972). Shift-share Analysis Revisited. Regional and Urban Economics, no. 2-3, pp. 249-261.

[12] Esteban-Marquillas, J.M. (1986). Income-Share Elasticity and the Size Distribution of Income. International Economic Review, vol. 27, pp. 439-444. doi: 10.2307/2526515

[13] Ezcurra, R., Gil, C., Pascual, P., \& Rapún, M. (2005). Regional Inequality in the European Union: Does Industry Mix Matter?. Regional Studies, vol. 39, pp. 679-697. doi: 10.1080/00343400500213473

[14] Ezcurra, R., \& Rapún, M. (2006). Regional Disparities and National Development Revisited the Case of Western Europe. European Urban and Regional Studies, vol. 13, pp. 355-369. doi: 10.1177/0969776406068590

[15] Fedoseeva, S. (2014). Are agri-food exports any special?: Exchange rate nonlinearities in European exports to the US. German journal of agricultural economics, vol. 63, no. 4, pp. 259-270.

[16] FoodDrinkEurope (2015). Data and Trends of the European Food and Drink Industry 2014-2015. Brussels, Belgium: FoodDrinkEurope.

[17] Gazel, R., \& Schwer, R.K. (1998). Growth of International Exports Among the States: Can a Modified Shift-Share Explain it?. International Regional Science Review, vol. 21, no. 2, pp. 185-204. doi: 10.1177/016001769802100205

[18] Girardi, R. (1993). Regional Equilibrium Growth and Disequilibrium Dynamics. A Location Elasticity Approach. Rotterdam, The Netherlands: Erasmus Universiteit.

[19] Hellman, D.A. (1974). Agglomeration economies: A model of regional export activity. Growth and Change, vol. 5, pp. 12-17.

[20] Kandilov, I.T., \& Zheng, X. (2011). The impact of entry costs on export market participation in agriculture. Agricultural Economics, vol.42, no. 5, pp. 531-546. doi: 10.1111/j.1574-0862.2010.00530.x

[21] Kitson, M., Martin, R., \& Tyler, P. (2004). Regional Competitiveness: An Elusive yet Key Concept?. Regional Studies, vol. 38, no. 9, pp. 991-999. doi: 10.1080/0034340042000320816

[22] Maertens, M. (2011). Supply Chains in Export Agriculture, Competition, and Poverty in Sub-Saharan Africa. European Review of Agricultural Economics, vol. 38, no. 4, pp. 615617. doi: 10.1093/erae/jbr049 
[23] Markusen, A., Noponen, H., \& Driessen, K. (1991). International Trade, Productivity and US Regional Job Growth: A Shift-Share Interpretation. International Regional Science Review, vol. 14, no. 1, pp. 15-39.

[24] Maudos, J., Pastor, J.M., \& Serrano, L. (2008). Explaining the US-EU productivity growth gap: Structural change vs. intra-sectoral effect. Economics Letters, vol. 100, pp. 311-313. doi: 10.1016/j.econlet.2008.02.017

[25] Mercasa (2012). Alimentación en España 2012. Madrid: Mercasa.

[26] Mayor, M., \& López, A. (2005). Spatial shift-share analysis: new developments and some findings for the Spanish case. 45th Congress of the European Regional Science Association, Amsterdam, The Netherlands.

[27] Mayor, M., \& López, A. (2008). Spatial shift-share analysis versus spatial filtering: an application to the Spanish employment. Empirical Economics, vol. 34, no. 1, pp. 123142.

[28] Minondo, A., \& Requena, F. (2012). The intensive and extensive margins of trade: decomposing exports growth differences across Spanish Regions. Investigaciones Regionales, vol. 23, pp. 53-76.

[29] Morley, B., \& Morgan, W. (2008). Causality between exports, productivity and financial support in European Union agriculture. Regional Studies, vol. 42, no. 2, pp. 189-198. doi: $10.1080 / 00343400601142738$

[30] Park, H. (2009). A Scheme of the Agriculture Export Logistics Improvement in E-Trade Era. International Commerce and Information Review, vol. 11, no. 2, pp. 49-66.

[31] Reig, E.M. (2007). Competitividad, crecimiento y capitalización de las regiones españolas. Bilbao, Spain: Fundación BBVA.

[32] Serrano, R., \& Pinilla, V.J. (2010). Agricultural and Food Trade in European Union Countries, 1963 - 2000: A gravity equation aproach. Documentos de trabajo de la Asociación Española de Historia Económica, vol. 7.

[33] Serrano, R., \& Pinilla, V.J. (2011). The Evolution and Changing Geographical Structure of World Agri-food Trade, 1951-2000. Revista de historia industrial, vol. 46, pp. 97-125.

[34] Sirakaya, E., Choi, H., \& Var, T, (2002). Shift-share analysis in tourism: examination of tourism employment change in a region. Tourism Economics, vol. 8, pp. 303-324. doi: $10.5367 / 000000002101298142$

[35] Suedekum, J., Blien. U., \& Ludsteck, J. (2006). What has caused regional employment growth differences in Eastern Germany?. Jahrbuch für Regionalwissenschaft, vol. 26, pp. 51-73. doi: 10.1007/s10037-005-0077-2

[36] Ucak H., Ozturk I., \& Sarac T.B. (2012). Total Factor Productivity and Export Relationship: The Case For Agriculture Sector In Four Mediterranean Countries. Actual Problems of Economics, vol. 9, no. 135, pp. 514-525.

[37] Williamson, R. (2006). Forecasting Regional Exports. New Tests of Shift-Share Techniques. Growth and Change, vol. 11, no. 2, pp. 19-25.

[38] Zhao X.H., Liu X.S., \& Ma P.C. (2006). Shift-Share Analysis of Industrial Structure in Hebei Province. International Conference on E-Learning. E-Business, Enterprise Information Systems and E-Government, Hong Kong. 